8 Hay PE, Lamont RF, Taylor-Robinson D, Morgan DJ, Ison C, Pearson J. Abnormal bacterial colonisation of the genital tract and subsequent preterm delivery and late miscarriage. BMJ 1994;308:295-8.

9 Meis PJ, Goldenberg RL, Mercer B, Moawad A, Das A, McNellis D, et al. The preterm prediction study: significance of vaginal infections. Am J Obstet Gynecol 1995;173:1231-5.

10 Brocklehurst $\mathrm{P}$, Hannah $\mathrm{M}$, McDonald $\mathrm{H}$. Interventions for treating bacterial vaginosis in pregnancy. Cochrane Database Syst Rev 2000;(2): CD000262.

11 Leitich H, Brunbauer M, Bodner-Adler B, Kaider A, Egarter C, Husslein P. Antibiotic treatment of bacterial vaginosis in pregnancy: a meta-analysis. Am J Obstet Gynecol 2003;188:752-8.

12 Carey JC, Klebanoff MA, Hauth JC, Hillier SL, Thom EA, Ernest JM, et al. Metronidazole to prevent preterm delivery in pregnant women with asymptomatic bacterial vaginosis. N Engl J Med 2000;342:534-40.
13 Cotch MF, Hillier SL, Gibbs RS, Eschenbach DA. Epidemiology and outcomes associated with moderate to heavy Candida colonization during pregnancy. Am J Obstet Gynecol 1998;178:374-80.

14 Nugent RP, Krohn MA, Hillier SL. Reliability of diagnosing bacterial vaginosis is improved by a standardized method of Gram stain interpretation. J Clin Microbiol 1991;29:297-301.

15 Ugwumadu A, Manyonda I, Ried F, Hay P. Effect of early oral clindamycin on late miscarriage and preterm delivery in asymptomatic women with abnormal vaginal flora and bacterial vaginosis: a randomised controlled trial. Lancet 2003;361:983-8.

16 Lamont RF, Dunchan SLB, Mandal D, Basset P. Intravaginal clindamycin to reduce preterm birth in women with abnormal genital tract flora. Obstet Gynecol 2003;101:516-22.

(Accepted 23 June 2004)

doi 10.1136/bmj.38169.519653.EB

\title{
Commentary: Does screening reduce preterm births?
}

\section{Anna Alanen}

Department of Obstetrics and Gynaecology, University of Turku, Kiinamyllynkatu $4-8$, FIN-20520 Turku, Finland Anna Alanen senior consultant anna.alanen@utu.fi
Preterm birth is one of the most important problems in modern obstetrics. As the connection between ascending infection and preterm birth is undisputed, much research has focused on finding infectious risk factors suitable for screening. In the study by Kiss et al, asymptomatic pregnant women were screened and randomised to treatment during the second trimester for bacterial vaginosis, Candida, and trichomoniasis. ${ }^{1}$ Bacterial vaginosis has proved to be associated with an increased risk of preterm birth. Unfortunately, in several trials, intervention with antenatal antibiotic treatment-vaginal or systemic-has mostly failed to reduce the rate of preterm births, in spite of successful eradication of bacterial vaginosis. ${ }^{2}$

Although the incidence of preterm birth was lower in the intervention group in the study by Kiss et al, the treatment of bacterial vaginosis did not significantly reduce the rate of preterm birth. The difference occurred mostly in women with a normal vaginal flora, who received no treatment, and among women colonised with Candida, which is surprising since Candida has not been considered to be a risk factor for preterm birth. The study of Kiss et al is therefore in agreement with most previous studies concerning the failure of antenatal treatment of bacterial vaginosis to prevent preterm birth. The rate of preterm birth was, however, significantly lower in the intervention group, implying that factors connected to the screening programme, including the role of candidiasis, deserve further studies.

It is interesting to speculate why successful treatment of bacterial vaginosis does not reduce the increased risk of preterm birth. There might be several reasons for this. Bacterial vaginosis is not an infection caused by a single microbe such as Candida or Chlamydia, but a condition where normal vaginal flora is replaced by a microbiota, which contains a wide variety of bacterial species. It is not known whether differences in the flora of bacterial vaginosis are important, and if so, what the characteristics of a "risky" flora are. Antibiotic treatment is bound to cause selection among the bacterial species and may leave the "dangerous" bacteria alive, although the treatment seems successful. Metronidazole and clindamycin have been used most often in trials. Metronidazole has proved ineffective, ${ }^{3}$ but systemic clindamycin may reduce the rate of preterm birth. ${ }^{4}$
Different tests can be used to detect bacterial vaginosis. The tests used might lead to differences in study populations, although no difference was observed in the accuracy of the various tests to predict preterm birth. $^{5}$

Another feature typical of bacterial vaginosis is the lack of lactobacilli in the vagina. Normal flora anywhere in the body is usually protective, and it may be the lack or incomplete restoration of this protection that allows pathogens to ascend. Little is known about the local immune function and protection in the vagina and cervix, which surely has an important role in preventing ascending infection. Abnormal vaginal microbiota could even be secondary to defective protection of the mucosal immune system.

We should know more about the specific factors that are responsible for the increased risk of preterm birth so that more accurate screening tests and more effective prophylactic treatment can be developed.

1 Kiss H, Petricevic L, Husslein P. Prospective randomised controlled tria of an infection screening programme to reduce the rate of preterm delivery. BMJ 2004;329:371-4.

2 McDonald H, Brocklehurst P, Parsons J, Vigneswaran R. Antibiotics for treating bacterial vaginosis in pregnancy. Cochrane Database Syst Reu 2003(2):CD000262.

3 Carey JC, Klebanoff MA, Hauth JC, Hillier SL, Thom EA, Ernest JM, et al. Metronidazole to prevent preterm delivery in pregnant women with asymptomatic bacterial vaginosis. National Institute of Child Health and Human Development Network of Maternal-Fetal Medicine Units. $N$ Engl IMed 2000;342:534-40.

4 Ugwumadu A, Manyonda I, Reid F, Hay P. Effect of early oral clindamycin on late miscarriage and preterm delivery in asymptomatic women with abnormal vaginal flora and bacterial vaginosis: a randomised controlled trial. Lancet 2003;361:983-8.

5 Honest H, Bachmann LM, Knox EM, Gupta JK, Kleijnen J, Khan KS. The accuracy of various tests for bacterial vaginosis in predicting preterm birth: a systematic review $B J O G$ 2004:111:409-22.

\section{Endpiece}

\section{No hands}

I would like to see the day when somebody would be appointed surgeon somewhere who had no hands, for the operative part is the least part of the work.

Harvey Cushing. Letter to Dr Henry Christian, 20 November 1911

Syed Hasan, senior house officer in surgery, Great Yarmouth 